\author{
JAN KotlarZ ${ }^{1}$, NATALia ZalewskA ${ }^{1,2}$ \\ ${ }^{1}$ Zakład Teledetekcji \\ Instytut Lotnictwa \\ Al. Krakowska 110/114, 02-256 Warszawa \\ ${ }^{2}$ Centrum Badań Kosmicznych PAN \\ Bartycka 18A, 00-716 Warszawa \\ E-mail: jan.kotlarz@ilot.edu.pl \\ natalia.zalewska@ilot.edu.pl
}

\title{
CHARAKTERYSTYKA SPEKTRALNA EGZOPLANET O LEŚNYM TYPIE POWIERZCHNI W ZAKRESIE WIDZIALNYM I PODCZERWIENI. STAN WIEDZY PRZED ROZPOCZECIEM OBSERWACJI PRZEZ TELESKOP JWST
}

\section{WSTEP}

Obecnie w najbliższym sąsiedztwie Słońca prawie 4.000 zidentyfikowanych planet krąży wokół swoich macierzystych gwiazd (Claudi 2017). Ponieważ planety sa w porównaniu do towarzyszacych im gwiazd bardzo ciemnymi obiektami astronomicznymi, jedynie znikoma część $z$ nich (ok. 3\%) została zaobserwowana w sposób bezpośredni (OlliviER i MAUREL 2014, CHAKRABARTI i współaut. 2016). Najbardziej popularne sposoby detekcji i pozyskania danych dotyczacych parametrów fizycznych egzoplanet opieraja się na metodach pośrednich, takich jak: fotometria tranzytów na tarczy gwiazd, analiza prędkości radialnych gwiazd spowodowanych oddziaływaniem grawitacyjnym planet oraz mikrosoczewkowanie grawitacyjne (UDALSKI i współaut. 2005).

Chociaż podstawowa charakterystyka, zawierająca masę, promień, gęstość, odległość od gwiazdy (FITZPATRICK i współaut. 2016), a także skład chemiczny atmosfery (PARMENTIER i współaut. 2015) dla planet odkrytych metoda tranzytu jest w obecnym stanie wiedzy możliwa do określenia, to nadal stosowane w detekcji metody pośrednie uniemożliwiaja lub utrudniają określenie pokrycia terenu tych planet za pomoca analizy wielospektralnej (ZALEWSKA 2013). Pośród stosowanych w modelach spektralnych typów powierzchni, takich jak: planety skaliste, gazowe, lodowe i oceaniczne (FUJII i współaut. 2017), swoje miejsce znalazł leśny i częściowo leśny typ powierzchni (SCHWIETERMAN i współaut. 2015, WEI S. i współaut. 2017). Jednym z celów planowanej na kwiecień 2019 r. misji JWST (teleskop Jamesa Webba; ang. James Webb space telescope) jest właśnie detekcja biosfer egzoplanet, w tym powierzchni podobnych spektralnie do lesistych powierzchni na Ziemi, w obrębie skalistych egzoplanet (KASTING i współaut. 2014).

Pierwsze koncepcje obserwatoriów egzoplanet podobnych do Ziemi, umieszczanych na orbicie okołoziemskiej, wokół punktu libracyjnego $\mathrm{L}_{2} \quad(1,5$ miliona $\mathrm{km}$ od Ziemi) lub okołosłonecznej, formułowane były już w latach 90. XX w. (DRESSLER i współaut. 1996). Po 2000 r. podjęto wiele prób określenia prawdopodobnego wpływu powierzchni pokrytych biomasa oraz gazowych produktów procesów spełniajacych taka sama funkcję co fotosynteza na Ziemi, na obserwacje wielospektralne egzoplanet, które będa prowadzone w przyszłości przez JWST. Celem tej publikacji jest zestawienie wyników dotyczących tego typu powierzchni i odpowiedź na pytanie, czy i w jaki sposób teledetekcyjna wiedza o lasach na Ziemi może być zaaplikowana do algorytmiki analizy danych spektralnych pod katem poszukiwania egzoplanet o lesistym typie powierzchni, za pomoca danych pozyskanych w przyszłości przez JWST w świetle widzialnym i podczerwieni $(0,6-5,0 \mu \mathrm{m})$. 


\section{METODYKA DETEKCJI BIOSYGNATUR}

Planety i księżyce mogace być miejscami o sprzyjajacych warunkach dla rozwoju biosfer; musza spełniać ściśle zdefiniowane warunki. Po pierwsze, musza znajdować się w odległości od gwiazdy umożliwiającej obecność wody w stanie płynnym. $\mathrm{Na}$ bazie wody lub potencjalnie innej substancji w stanie ciekłym musi występować cykl analogiczny do cyklu hydrologicznego na Ziemi. Planetom, które nie spełniaja powyższych warunków (np. sa zbyt daleko od gwiazdy, nie posiadaja atmosfery itp.) przypisywane jest małe prawdopodobieństwo istnienia na nich biosfer. Należy podkreślić, że oprócz promieniowania gwiazd, możliwe sa inne źródła energii powodujące istnienie wody $\mathrm{w}$ stanie ciekłym, a nawet oceanów pokrywajacych całe ciało niebieskie (np. energia pływowa dla Europy, księżyca Jowisza). Dla pozostałych obiektów zasadna jest realizacja zaawansowanego przetwarzania danych wielospektralnych mogacych określić warunki atmosferyczne (gęstość, skład chemiczny), separację obszarów o różnym typie powierzchni oraz przeprowadzić detekcje zmian $\mathrm{w}$ czasie $\mathrm{w}$ atmosferze $\mathrm{i}$ na powierzchni. $\mathrm{Na}$ podstawie parametrów fizycznych planet i ich gwiazd można zaproponować modele opisujące procesy na planecie wraz $z$ przypisanymi im biosygnaturami występujacymi jako elementy powierzchni lub składnik atmosfery.

\section{DEFINICJA BIOSYGNATURY W ASTROBIOLOGII}

Definicje biosygnatur sa bardzo szerokie pod względem pojęciowym. Jedna $z$ najwcześniejszych zaproponowano $\mathrm{w}$ pracy DES MARAIS i współaut. (2002), określając ja jako cechę zróżnicowania natężenia promieniowania elektromagnetycznego w różnych zakresach spektralnych lub polaryzacjach, którego przyczyna moga być produkty życia biologicznego. Współcześnie przyjmuje się, że jest to obfitość składników atmosferycznych, typów pokrycia powierzchni lub nawet znaczne zróżnicowanie samej sygnatury spektralnej reflektancji powierzchni planety (SCHWIETERMAN i współaut. 2017). W ostatnich latach bardziej skupiono się na poszukiwaniu potencjalnych produktów dowodzacych istnienia biosfer $\mathrm{w}$ atmosferach planet, ze względu na trudność detekcji parametrów samych powierzchni. Detekcja charakterystycznych cech sygnatur spektralnych dla np. tlenu lub dwutlenku węgla była prowadzona również w Układzie Słonecznym podobnymi technikami (ZALEWSKA i współaut. 2017). Można przyjać, że biosygnatura jest „przedmiot, substancja lub wzorzec spektralny i/lub czasowy, którego pochodzenie wymaga czynnika biologicznego" (DES MARAIS i współaut. 2008). Biosygnatury możemy podzielić na: gazowe [np. tlen czasteczkowy $\left(\mathrm{O}_{2}\right)$ wytwarzany jako produkt uboczny fotosyntezy, a nastepnie poprzez reakcje fotochemiczne przekształcany w ozon $\left(\mathrm{O}_{3}\right)$ w stratosferze], powierzchniowe [np. „red edge” - wzorzec spektralny zakładajacy zróżnicowanie reflektancji przez liście roślin $\mathrm{w}$ pasmach czerwonym i bliskiej podczerwieni (ang. near-infra red, NIR)] oraz majace charakter zmienności w czasie (np. zmiana stężenia gazu $\mathrm{w}$ atmosferze lub zmiana albedo powierzchni, gdy można je uzasadnić reakcja biosfery na sezonowa lub dobowa zmianę warunków na planecie). Trzeba pamiętać, że tego typu definicja może skutkować podniesieniem prawdopodobieństwa fałszywego alarmu i jest kwestionowana przez część środowiska astrobiologów (SCHWIETERMAN i współaut. 2017).

\section{FIZYCZNE WARUNKI DLA MAS I ORBIT EGZOPLANET}

Zakłada się, że aby na planecie mogła występować biosfera, musi ona być ulokowana w przedziale odległości od gwiazdy umożliwiajacej stała obecność wody w stanie ciekłym (ang. habitable zone, HZ). Odległość ta zależy od składu atmosfery, masy planety i typu gwiazdy (KOPPARAPU i współaut. 2013). Dla gwiazd ciagu głównego i masy planet porównywalnej do Ziemi oszacowano dopuszczalne granice $\mathrm{w}$ punktach odpowiadajacych parowaniu wody (granica wewnętrzna) oraz kondensacji $\mathrm{CO}_{2}$ (granica zewnętrzna) na odpowiednio 0,95 AU (ang. astronomical unit) i 1,37 AU (KASTING i współaut. 1993) lub 0,99 AU i 1,70 AU (KopPARAPU i wspó1aut. 2013). Porównanie efektywnej temperatury gwiazd i półosi małej orbity egzoplanet przedstawia Ryc. 1

Większość opracowań dotyczących tego tematu zakłada dodatkowo dwa parametry: atmosferę typu $\mathrm{N}_{2}-\mathrm{CO}_{2}-\mathrm{H}_{2} \mathrm{O}$ i obecność cyklu węglanowo-krzemianowego. Jest oczywistym, że dostępność wody jest kluczowym aspektem również dla istnienia i funkcjonowania ekosystemów leśnych. Zarówno badania lasów tropikalnych w dorzeczu Amazonki w 2005 r. i 2010 r., jak również badania wpływu suszy 2015 r. w Polsce na drzewostan debowy wykazaly stosunkowo niewielki niedobór wody, jako przyczynę wzrostu śmiertelności drzew, zauważalnej zmiany reflektancji całych kompleksów leśnych w paśmie NIR i poziomu wykorzystania atmosferycznego $\mathrm{CO}_{2}$ (DoughtY i współaut. 2015, NASIŁOWSKA i współaut. 2016). Precyzja w wyznaczeniu orbity planety, strumienia promieniowania gwiazdy $\mathrm{w}$ powiazaniu $\mathrm{z}$ warunkami atmosferycznymi (np. występowaniem 


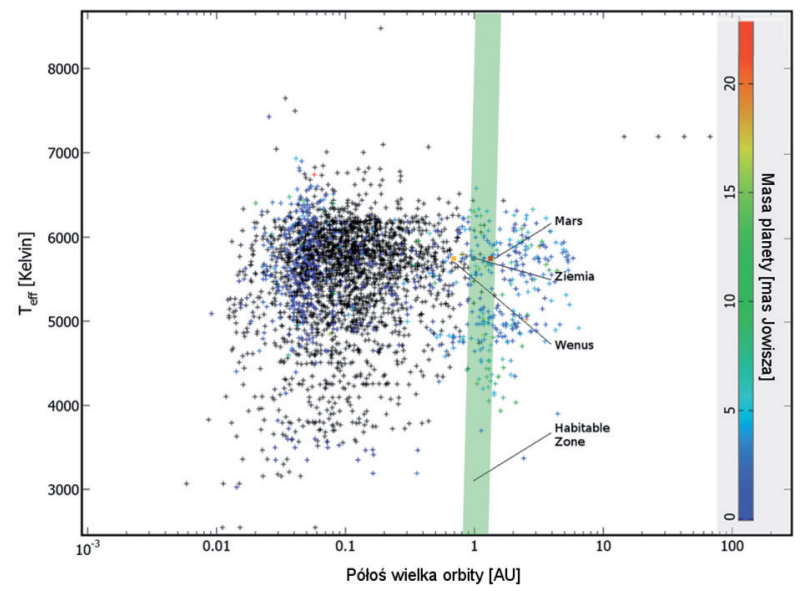

Ryc. 1. Zestawienie temperatur efektywnych $T_{\text {eff }}$ gwiazd, odległości planet od gwiazd i ich mas w kontekście minimalnej i maksymalnej dopuszczalnej odległości dla której na planecie może istnieć woda w stanie ciekłym (Habitable Zone, HZ). Dodatkowo zaznaczono Wenus, Ziemię i Marsa (źródło: dane dotyczace egzoplanet: exoplanets.org, dane dotyczace Marsa, Ziemi i Wenus: opracowanie własne).

zachmurzenia) jest zatem kluczowa dla wyznaczenia potencjalnych kandydatów do obserwacji pod względem obecności tak wrażliwych ekosystemów, jak ekosystem leśny.

\section{ATMOSFERA}

Zakłada się, że detekcja biosygnatur spektralnych wymaga modelowania widm będacych suma promieniowania odbitego, emitowanego lub pochłoniętego przez egzoplanety (BERDYUGINA i KUHN 2017). Jednym Z najprostszych podejść jest detekcja gazów biogennych, która może wstępnie klasyfikować kandydatów wartych dalszej obserwacji (GRENFELL i współaut. 2013). Modele atmosfer planet odpowiednich dla biomasy dziela się na dwa scenariusze. W pierwszym mo- delu atmosfera jest typu ziemskiego, tzn. zdominowana przez $\mathrm{N}_{2}, \mathrm{CO}_{2} \mathrm{i} \mathrm{H}_{2} \mathrm{O}$. Tlen cząsteczkowy $\mathrm{O}_{2}$ może, ale nie musi być znaczacym składnikiem atmosfery. Bardziej ogólnie, w atmosferze musza występować trzy składniki: gaz cieplarniany ulegajacy kondensacji, nie ulegajacy kondensacji oraz gaz będacy „tłem” (MARCQ i współaut. 2017). Alternatywne modele przypisane raczej dla planet o masie rzędu od kilku mas Ziemi do masy Neptuna zawieraja przede wszystkim wodór czasteczkowy $\left(\mathrm{H}_{2}\right)$ wraz $\mathrm{z}$ niewielka domieszka $\mathrm{CO}_{2}$. Należy zauważyć, że na Ziemi ten typ wodoru znaleźć można przede wszystkim w górnych warstwach atmosfery i chociaż jego źródłem są przede wszystkim reakcje fotochemiczne $z$ udziałem metanu $i$ innych węglowodorów, to również jego naturalnym źródłem mogą być: spalanie biomasy i odgazowanie oceanów (RAHN i współaut. 2002).

W ziemskim modelu atmosfery możemy wyróżnić biosygnatury pochodzace $z$ ekosystemów leśnych bezpośrednio (np. tlen, będaccy produktem fotosyntezy) lub pośrednio (np. ozon, będacy efektem reakcji fotochemicznej tlenu w stratosferze). Nie wszystkie gazowe biosygnatury sa pochodzenia wyłącznie biologicznego, dlatego uznanie ich w przyszłości jako dowodu pośredniego istnienia ekosystemów leśnych na planetach będzie zależało od kontekstu środowiskowego egzoplanety (MEADows i współaut. 2017).

Najważniejszymi biosygnaturami typu atmosferycznego sa: $\mathrm{O}_{2}, \mathrm{O}_{3}, \mathrm{~N}_{2} \mathrm{O}, \mathrm{CH}_{4}, \mathrm{CH}_{3} \mathrm{Cl}$, $\mathrm{C}_{2} \mathrm{H}_{6}, \mathrm{NH}_{3}$, siarczek dimetylu (DMS), disulfid dimetylu (DMDS) i $\mathrm{CH}_{3} \mathrm{SH}$ (SCHWIETERMAN i współaut. 2017). Trzeba podkreślić, że w ziemskich ekosystemach leśnych proces emisji azotynów, a szczególnie rola materii organicznej i kwasów huminowych w glebie, nie sa jeszcze do końca poznane (WEI J. i współaut. 2017). Metan jest na Ziemi efektem metabolizmu beztlenowego drobnoustro-

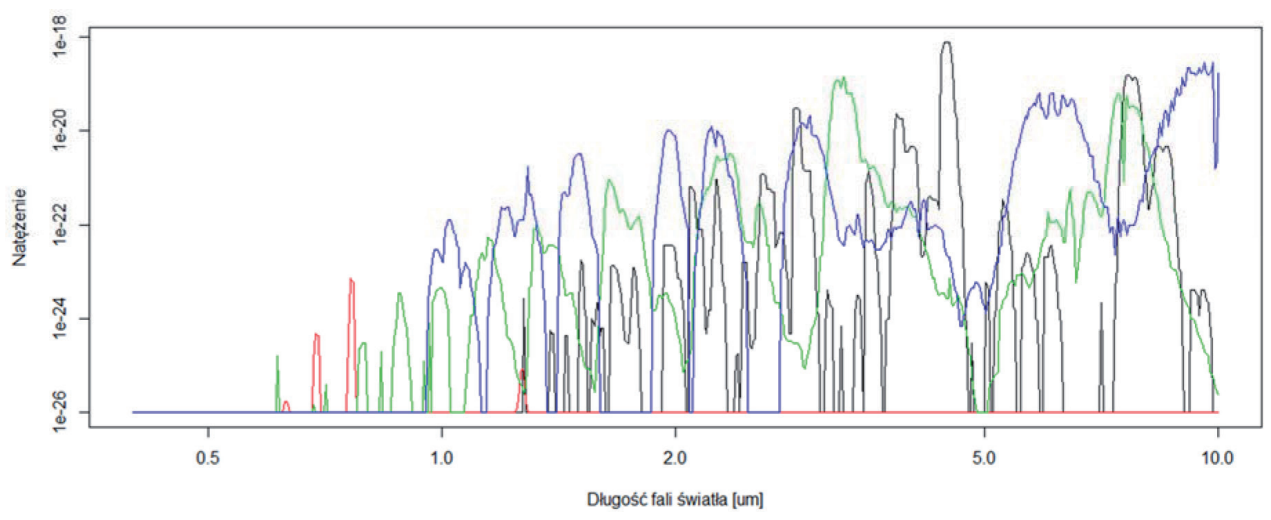

Ryc. 2. Intensywności $\left(\mathrm{cm}^{-1} / \mathrm{mol} \mathrm{cm}^{-2}\right)$ linii absorbcji biosygnatur: $\mathrm{O}_{2}$ (czerwony), $\mathrm{N}_{2} \mathrm{O}$ (czarny), $\mathrm{CH}_{4}\left(\mathrm{zie}^{-}\right.$ lony), $\mathrm{NH}_{3}$ (niebieski). Źródło: baza danych HITRAN 2012/opracowanie własne. 
jów, natomiast ważnym źródłem metanu sa również lasy obszarów mokradeł. Tego typu emisja może stanowić nawet $27 \%$ sezonowej emisji $\mathrm{CH}_{4}$ w ekosystemach w umiarkowanych podmokłych lasach, przy największym udziale wiosna i zima (PANGALA i wspólaut. 2015). Rośliny tropikalne i podzwrotnikowe sa głównym źródłem chlorometanu $w$ atmosferze (Kolusu i współaut. 2018), natomiast etan, amoniak i wodór cząsteczkowy moga być efektem pożarów lasów (LUTSCH i współaut. 2016). Dodatkowo, amoniak jest naturalnym produktem procesu transpiracji szparkowej (HANSEN i współaut. 2017).

Detekcja wszystkich powyższych biosygnatur może być prowadzona zarówno w paśmie widzialnym, jak i w podczerwieni. Sygnatury spektralne absorbcji wybranych zwiazków w zakresie 0,4-10,0 $\mu \mathrm{m}$ przedstawia Ryc. 2.

\section{WODA W STANIE CIEKŁYM}

Sama obecność planety w HZ nie jest wystarczajaca do stwierdzenia, że jest na niej obecna woda w stanie ciekłym umożliwiajaca istnienie biosfery. Przykładem tego typu planety jest chociażby Mars. Czerwona planeta wraz $z$ Ziemia znajduja się $w$ HZ Układu Słonecznego. Pory roku, takie jak na Ziemi, mogłyby sprzyjać powstaniu życia. Dodatnia temperatura dochodzaca w strefie równikowej do $30^{\circ}$ oraz czas trwania doby $\left(24^{\mathrm{h}} 39^{\mathrm{m}}\right)$ skłaniaja do spekulacji na temat istnienia życia na tej planecie. Jednak istnieje decydujacy czynnik, który poważnie utrudnia jego rozwój: brak ciekłej wody. Niestety, ciśnienie atmosferyczne na Marsie jest tak niskie ( $\sigma$ mbar), że uniemożliwia istnienie wody $\mathrm{w}$ tej postaci. Chociaż słaba atmosfera $\left(\mathrm{CO}_{2}\right)$ mogłaby stanowić dogodne środowisko dla organizmów żywych, to brak pola magnetycznego naraża potencjalne organizmy na promieniowanie kosmiczne, a w konsekwencji na śmierć.

W ramach programu VIKING w latach 70. XX w. lądowniki, które badały skład chemiczny gruntu marsjańskiego, nie dostarczyły żadnych wyników świadczących o występowaniu życia. Badania te na podstawie przesłanych zdjęć dowodziły występowania kanałów na Marsie. Gdyby tymi kanałami płynęła kiedyś woda, to potencjalnie byłyby one korzystnym środowiskiem do rozwoju ekosystemów. Ostatnie badania łazika Curiosity wykryły śladowe ilości węglowodorów na planecie oraz kluczowe składniki chemiczne do życia w glebie, w tym siarkę, azot, wodór, tlen i fosfor (MANNE i współaut. 2017). Niestety, życia nawet uśpionego nie udało się znaleźć do tej pory, a wspomniane kanały w świetle ostatnich badań sa prawdopodobnie zastygłymi potokami bardzo rzadkiej, pierwotnej lawy oraz jej interakcji $z$ lodem (WITEK i CZECHOWSKI 2016). Wynika $z$ tego, że występowanie na obiekcie astrofizycznym form przypominajacych ziemskie koryta rzek nie jest dowodem na obecność wody $\mathrm{w}$ postaci ciekłej na powierzchni planety.

Przykład Marsa pokazuje, że do prawidłowego opisu warunków rozwoju potencjalnych biosfer niezbędna jest detekcja wody w stanie ciekłym w sposób bezpośredni. Najprostsza metoda detekcji dużych zbiorników wodnych byłaby obserwacja błysku, jeśli planeta mogłaby być obserwowana pod względnie dużymi katami fazowymi (RoBINSON i współaut. 2014). Heterogeniczność ocean-ziemia można również próbować wykryć za pomoca analizy widm w szeregach czasowych o niewielkich interwałach czasowych pomiedzy kolejnymi obserwacjami (COWAN i STRAIT 2013). Zmienność czasowa obserwowanej jasności planet powiązana została $\mathrm{w}$ tych pracach $z$ ruchem obrotowym planet i w efekcie zmiennościa reflektancji całej planety, będącej średnią ważona $\mathrm{z}$ reflektancji trzech typów powierzchni: lodu, lądu i oceanów. Przez analize statystyczna PCA (ang. principal component analysis) i metody Simplex Shrink-Wrapping i Rotational Unmixing tworzone moga być południkowe mapy planet, pokazujące przestrzenne zróżnicowanie tych trzech typów powierzchni. Metoda ta została rozwinięta w Zakładzie Teledetekcji Instytutu Lotnictwa i w Instytucie Badawczym Leśnictwa w kontekście detekcji i opisu powierzchni typu leśnego (CZAPSKI i współaut. 2014) oraz jego zróżnicowania, w tym różnorodności gatunkowej (KOTLARZ i współaut. 2016, KOTLARZ i KACPRZAK 2017) oraz wybranych parametrów ekosystemów leśnych: zawartości wody zwiazanej $\mathrm{w}$ liściach $\mathrm{i} \mathrm{w}$ glebie (NASIŁOWSKA i współaut. 2016) i defoliacji (KACPRZAK i współaut. 2018). Metoda pośrednia detekcji zbiorników wodnych jest oszacowanie temperatury powierzchni planety, przez obserwacje prowadzone w kanałach średniej podczerwieni, oraz ciśnienia, przez analize rozpraszania Rayleigha. Planeta o odpowiedniej temperaturze $i$ ciśnieniu oraz charakteryzująca się obecnościa pasm absorpcji $\mathrm{H}_{2} \mathrm{O}$, prawdopodobnie będzie światem sprzyjającym obecności biosfer, w tym ekosystemów leśnych (DES MARAIS i współaut. 2002, ROBINSON 2017).

\section{DETEKCJA POWIERZCHNI LEŚNYCH}

Oparta o prace FUHRMANNA (1999) oraz COWANA i STRAITA (2013) metoda separacji typów powierzchni na podstawie danych wielospektralnych, pozwala teoretycznie na detekcję powierzchni typowo leśnych. Ewolucję czasowa danych spektralnych EPOXI 

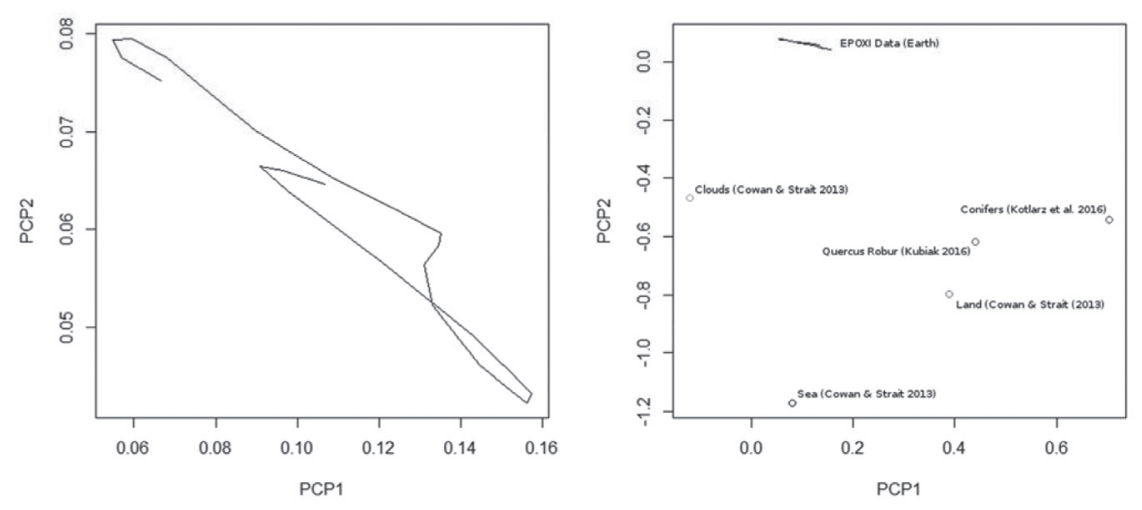

Ryc. 3. Dane wielospektralne EPOXI obrazujace Ziemię jako jeden piksel z kolejnych 24 godzin (pełny obrót Ziemi wokół własnej osi) w zakresie 350-950 nm zrzutowane na płaszczyznę głównych składowych PCP (po lewej) oraz naniesione na PCP punkty odpowiadajace zrzutowanym sygnaturom spektralnym chmur, lądu i oceanu (COWAN i STRAIT 2013). Dodatkowo zaznaczone przykładowe dane zwiazane $z$ ekosystemami leśnymi: pomiar laboratoryjny sygnatury spektralnej Quercus Robur L. za pomoca spektrometru Evolution 220 (KUBIAK i współaut. 2016) oraz średnia reflektancja drzewostanu iglastego w nadleśnictwie Krotoszyn zmierzona za pomoca sześciokanałowej kamery wielospektralnej podczas lotu fotogrametrycznego w projekcie HESOFF (KOTLARZ i współaut 2016 - obszar nr 681 na Ryc. 4).

dla Ziemi, potraktowanej jako egzoplaneta i zrzutowanych na przestrzeń głównych składowych (ang. principal component plane, PCP) w trakcie jednej doby, uzupełnione o przykładowe dane spektralne dla różnych typów leśnego pokrycia powierzchni, pozyskane w trakcie projektu HESOFF przedstawia Ryc. 3.

Postępując zgodnie $z$ powyższa metodyką można próbować szukać wzorców spektralnych charakterystycznych dla obszarów leśnych lub dla procesów zachodzacych w tego typu ekosystemach. Najważniejszym z nich jest fotosynteza, która napędzana jest w sposób bezpośredni energia macierzystej gwiazdy.

\section{Fotosynteza}

Fotosynteza tlenowa jest źródłem najsilniejszej w skali planetarnej biosygnatury na Ziemi. Obecnie nie posiadamy jeszcze ostatecznych wyników badań pokazujących, jak promieniowanie różne od słonecznego wpływa na ten proces, w zakresie powstawania pigmentów takich jak chlorofil $-\mathrm{a}$ i $-\mathrm{b}$, oraz typów gazów wydzielanych do atmosfery jako produktów fotosyntezy. Badania nad fotosynteza i gazowymi produktami fotosyntezy na egzoplanetach, takich jak $\mathrm{O}_{4}$ lub $\mathrm{CO}$, prowadzone sa obecnie w NASA Astrobiology Institute - Virtual Planetary Laboratory (MEADOWS 2017). Zakładając konieczność istnienia procesu analogicznego do fotosyntezy na Ziemi, jego modelowanie zawierać powinno trzy zasadnicze zjawiska:

1. efekt fotoelektryczny: materiał (pigment) absorbuje foton w ściśle określonym zakresie spektralnym powodujacc wzbudzenie elektronów;

2. zastapienie wyrzuconych elektronów, powodujacce produkcję biogennych produktów przemiany materii $z$ utleniania reduktora;

3. zachowanie energii i jej uwolnienie powodujace emisje ciepła oraz fluorescencję.

Modele określające możliwość i formę procesu fotosyntezy $\mathrm{w}$ innych niż ziemskie środowiskach, pozwola na określenie biosygnatur: pigmentów i gazów biogenicznych (SCHWIETERMAN i współaut. 2017). Bardzo istotnym czynnikiem dla modelowania jest określenie długości fal światła dostępnych od macierzystej gwiazdy. Dla roślin na Ziemi dostępnymi długościami fali światła sa pasma widzialne i NIR. Wyjątkiem sa tu organizmy żyjace w środowisku wodnym, gdzie spektrum docierajacego światła słonecznego jest inne, powodujac odmienne właściwości spektralne zwiazane $\mathrm{z}$ procesem fotosyntezy (np. STEIGENBERger i współaut. 2004). Głównymi pigmentami dla ekosystemów leśnych będa tutaj chlorofile typów -a i -b. Ich charakterystyczne maksima absorpcji zawiera Tabela 1.

Model tlenowej fotosyntezy zaproponowanej w pracy WOLSTENCROFTA i RAVENA (2002) przewiduje, że wokół gwiazd karłowatych

Tabela1. Maksima absorpcji chlorofilu -a i -b.

\begin{tabular}{llll}
\hline \multirow{2}{*}{ Pigment } & \multicolumn{3}{l}{ Maksimum absorpcji $[\mu \mathrm{m}]$} \\
\cline { 2 - 4 } & Ultrafiolet $(\mathrm{UV})$ & Swiatło widzialne $(\mathrm{VIS})$ & Bliska podczerwień (NIR) \\
\hline Chlorofil -a & 0,35 & $0,43,0,67-0,68$ & 0,70 \\
\hline Chlorofil -b & 0,38 & 0,46 & 0,65 \\
\hline
\end{tabular}


typu M proces ten mógłby wykorzystywać fotony trzech długości fali światła $\mathrm{w}$ podczerwieni, analogicznie do przesunięć in vivo $\mathrm{u}$ bakterii fotosyntetycznych (np. do 0,76 i $0,90 \mu \mathrm{m})$. Gwiazdy typu widmowego $\mathrm{M}$, o masach 0,075-0,5 mas Słońca i temperaturze $4000 \mathrm{~K}$, maksimum emisyjności osiagaja $\mathrm{w}$ granicach $0,75 \mu \mathrm{m}$ (NIR). Ta właściwość sprawiałaby, że taki model fotosyntezy byłby efektywniejszy.

\section{Wzorzec typu "red edge"}

W zakresie ok. 0,7 $\mu \mathrm{m}$ dla zdrowych kompleksów leśnych obserwować możemy zasadniczą zmianę reflektancji pomiędzy maksimum absorpcji chlorofilu -a $(<0,68$ $\mu \mathrm{m})$ a maksimum reflektancji zwiazanym $\mathrm{z}$ odbiciem światła przez strukturę komórkowa liści $(>0,70 \mu \mathrm{m})$. Wzorzec ten jest powszechnie wykorzystywany $\mathrm{w}$ teledetekcji czynników związanych $z$ występowaniem obszarów zalesionych na Ziemi (np. PluTO-KossaKowSKA i współaut. 2017). Oprócz typowych zastosowań w oparciu o zdjęcia lotnicze i satelitarne (HORLER i współaut. 1983), był on również obserwowany $z$ sondy Galileo oraz w spektrum światła Ziemi odbitego od Księżyca (TURNBUll i współaut. 2006).

Wzorzec ten wydaje sie bardzo atrakcyjny dla detekcji dużych, w kontekście planetarnym, obszarów pokrytych roślinnościa (głównie lasów). Należy jednak zauważyć, że tego typu marker w spektrum biomasy może występować dla innej niż na Ziemi długości fali światła. Przy modelowaniu procesów fotosyntezy możliwe będzie zdefiniowanie zbioru potencjalnych długości promieniowania elektromagnetycznego, dla których wzorzec ten będzie obserwowalny. Ponadto, dla planet o powierzchni lesistej i dużej zawartości pary wodnej lub innego gazowego produktu fotosyntezy w atmosferze, należy skonfrontować widzialność wynikowej długości fali promieniowania $\mathrm{z}$ przezroczystością chmur w tym zakresie. Bezkrytyczna identyfikacja wzorca typu „red edge” jako lesistego typu powierzchni może powodować podniesienie prawdopodobieństwa fałszywego alarmu. $\mathrm{Na}$ Ryc. 4 przedstawiono typowy dla Ziemi kształt sygnatury spektralnej biomasy oraz zawierajace podobny wzorzec sygnatury cynobru i siarki.

Niektóre badania wskazuja, że wzorce w paśmie NIR byłyby łatwiejsze do detekcji niż występujące $\mathrm{w}$ paśmie widzialnym (TINETTi $\mathrm{i}$ współaut. 2006).

\section{DETEKCJA ZMIAN W CZASIE}

Wystepowanie znacznych obszarów leśnych na planecie może powodować zmienność obserwowanych biosygnatur zarówno w części gazowej, jak i powierzchniowej.

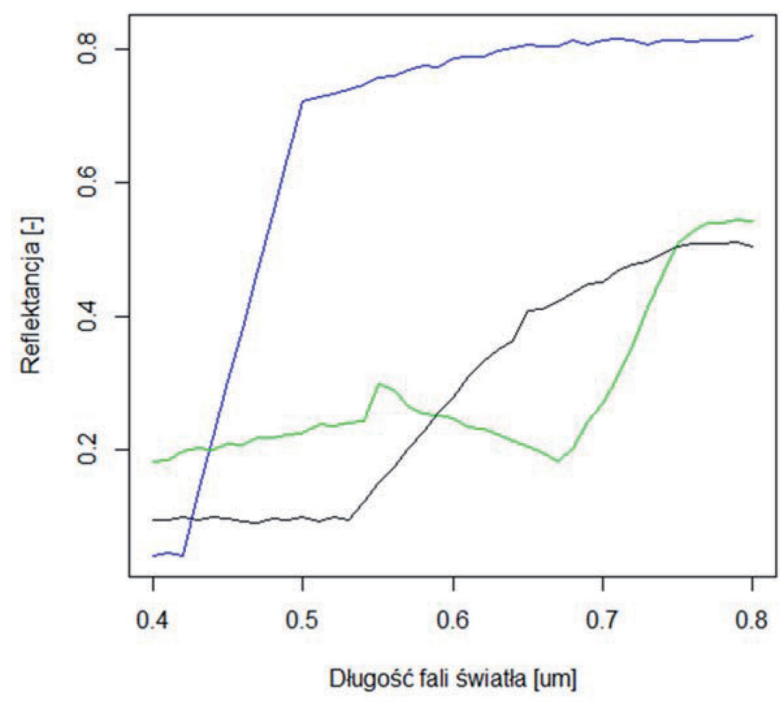

Ryc. 4. Wzorce typu "red edge" w spektrach reflektancji dla Quercus robur. wzorzec widoczny w zakresie 0,70 $\mathrm{\mu m}$ - kolor zielony (KUBIAK i wspó1aut. 2016), siarki: wzorzec widoczny w zakresie 0.40-0.50 $\mu \mathrm{m}$ - kolor niebieski (CLARK i wspó1aut. 2007), cynobru: wzorzec widoczny w zakresie 0,53-0,73 $\mu \mathrm{m}$ - kolor czarny (CLARK i współaut. 2007).

\section{Oscylacja biosygnatur gazowyc}

Najczęściej wskazywana biosygnatura różnicująca się w czasie jest na Ziemi sezonowa zmiana stężenia $\mathrm{CO}_{2}$ na półkuli północnej: 10-20 ppm (ang. parts per million) $\mathrm{w}$ stosunku do $\sim 3$ ppm zmienności wokół równika (CiAIS i współaut. 1995). Przyczyna tej zmienności jest sezonowa zmiana temperatury i nasłonecznienia, wpływajaca na produktywność tego gazu przez biomasę. Zmienność $\mathrm{CH}_{4}$ jest jedynie częściowo biogenna i bardziej skomplikowana. Detekcja tego typu zmienności na egzoplanetach w skali ziemskiej $\left(\sim 1-3 \%\right.$ dla $\left.\mathrm{CO}_{2} \mathrm{i} \mathrm{CH}_{4}\right)$ będzie najprawdopodobniej wykraczać poza możliwości instrumentów zarówno JWST, jak i innych obserwatoriów tego typu w przyszłości.

\section{Oscylacja biosygnatur powierzchniowych}

Najważniejsza koncepcja w monitoringu zmian powierzchniowych w skali okresu obiegu planety wokół swojej gwiazdy jest detekcja oscylacji wzorca typu "red edge" (SEAGER i współaut. 2005). Zarówno głębokość pasm absorpcji przez pigmenty, jak i wysokość wzorca "red edge" zmienia się podczas rocznego cyklu wegetacyjnego. Jesienne zmniejszenie intensywności procesu fotosyntezy przez lasy sprawia, że maksima staja się mniej wyraźne, a reflektancja biomasy w zakresie NIR spada (TUCKER 1979, CZAPSKI i współaut. 2015). Ponieważ zmienność 
Tabela 2. Wymagania aparatury odpowiedniej do detekcji biosygnatur.

\begin{tabular}{|c|c|c|c|c|}
\hline \multirow[t]{2}{*}{ Typ } & \multirow[t]{2}{*}{ Biosygnatura } & \multicolumn{2}{|l|}{ Wymagania } & \multirow{2}{*}{$\begin{array}{l}\text { Spełnienie wymagań } \\
\text { przez JWST }\end{array}$} \\
\hline & & zdolność rozdzielcza & rozdzielczość spektralna & \\
\hline \multirow{6}{*}{ 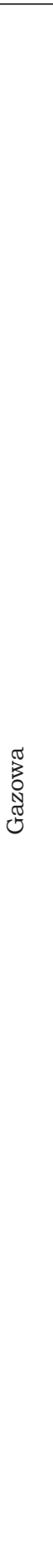 } & $\mathrm{O}_{2}$ & \multirow{6}{*}{$\begin{array}{l}\text { Brak wymagań in- } \\
\text { nych niż podczas } \\
\text { rejestracji krzywych } \\
\text { blasku. Detekcja } \\
\text { prowadzona podczas } \\
\text { pierwszej i ostatniej } \\
\text { fazy tranzytu plane- } \\
\text { ty przed tarcza jej } \\
\text { gwiazdy }\end{array}$} & $\begin{array}{l}\text { Maksima absorpcyjne: } 0,200 ; 0,445 \text {; } \\
0,475 ; 0,53 ; 0,57 ; 0,63 ; 6,40 \text { (słabe) } \\
\mu \mathrm{m} .\end{array}$ & $\begin{array}{l}\text { Rejestracja maksimów } \\
0,63 \text { i } 6,40 \mu \mathrm{m} .\end{array}$ \\
\hline & $\mathrm{O}_{3}$ & & $\begin{array}{l}\text { Pasmo absorpcyjne Hartley-Huggin- } \\
\text { s'a w zakresie } 0,15-0,35 \mu \mathrm{m} \text {, słabsze } \\
\text { pasmo absorpcji w zakresie } 0,5-0,7 \\
\mu \mathrm{m} \text {, kilka słabych pasm absorpcyj- } \\
\text { nych w podczerwieni: } 2,05 ; 2,15 \text {; } \\
2,5 ; 3,3 ; 3,6 ; 4,6 ; \text { i } 4,8 \mu \mathrm{m} \text {; wyraź- } \\
\text { ne pasmo reflektancji w kanale } 9,65 \\
\mu \mathrm{m} .\end{array}$ & $\begin{array}{l}\text { Rejestracja słabego pa- } \\
\text { sma absorpcji 0,5-0,7 } \\
\mu \mathrm{m} \text { oraz reflektancji w } \\
\text { zakresie } 9,65 \mu \mathrm{m} .\end{array}$ \\
\hline & $\mathrm{CH}_{4}$ & & $\begin{array}{l}\text { Silne pasma absorpcji } 1,65 ; 2,4 ; \\
3,3 ; \text { i } 7-8 \mu \mathrm{m} \text { częściowo pokrywające } \\
\text { się z pasmami absorpcji } \mathrm{H}_{2} \mathrm{O} \text { i } \mathrm{N}_{2} \mathrm{O} \text {. } \\
\text { Wymagana jest wysoka rozdzielczośc } \\
\text { spektralna. }\end{array}$ & $\begin{array}{l}\text { Wszystkie pasma ab- } \\
\text { sorpcji } \quad \text { rejestrowane } \\
\text { przez JWST, rozdziel- } \\
\text { czość spektralna jest } \\
\text { zapewniona przez istru- } \\
\text { menty NIRSpec i MIRI. }\end{array}$ \\
\hline & $\mathrm{N}_{2} \mathrm{O}$ & & $\begin{array}{l}\text { Pasma absorpcji } 3,7 ; 4,5 ; 7,8 ; 8,6 \text { i } \\
17 \mu \mathrm{m} \text {, słabe pasma absorpcji mię- } \\
\mathrm{dzy} 1,3 \text { a } 4,2 \mu \mathrm{m} \text { i } 9,5-10,7 \mu \mathrm{m} \text { czę- } \\
\text { ściowo pokrywajace się z pasmami } \\
\text { absorpcji } \mathrm{H}_{2} \mathrm{O}, \mathrm{CO}_{2}{\text { i } \mathrm{CH}_{4} \text {. Wymaga- }}_{\text {ne obserwacje przy bardzo wysokiej }} \\
\text { rozdzielczości spektralnej na pozio- } \\
\text { mie identyfikacji poszczególnych linii } \\
\text { absorpcyjnych. }\end{array}$ & $\begin{array}{l}\text { Ze względu na nakłada- } \\
\text { nie się pasm absorpcyj- } \\
\text { nych detekcja możliwa } \\
\text { tylko w przypadku re- } \\
\text { jestracji waskich zakre- } \\
\text { sów spektralnych lub } \\
\text { dla planet gdzie } \mathrm{H}_{2} \mathrm{O} \text { jest } \\
\text { dominującym składni- } \\
\text { kiem atmosfery. }\end{array}$ \\
\hline & $\begin{array}{l}\text { Gazy zawie- } \\
\text { rające siarkę }\end{array}$ & & $\begin{array}{l}\text { Charakterystyczne cechy sygnatur } \\
\text { znajduja się } \mathrm{w} \text { podczerwieni } \mathrm{w} \text { za- } \\
\text { kresach } 6-7 \mu \mathrm{m}, \sim 10 \mu \mathrm{m} \text { i } \sim 15 \mu \mathrm{m} \text {. } \\
\text { Najsilniejsza absorpcja w zakresie } \\
\text { środkowej podczerwieni } 7 \mu \mathrm{m}, 8-9 \\
\mathrm{i} 17 \mu \mathrm{m} \text {. } \mathrm{CH}_{3} \mathrm{SH} \text { ma maksima ab- } \\
\text { sorpcji dla } 6-7 \mu \mathrm{m}, 8-12 \mu \mathrm{m} \text { i } 14-15 \\
\mu \mathrm{m} \text {. Wszystkie te gazy maja właści- } \\
\text { wości absorpcyjne, które pokrywaja } \\
\text { się z pasmem } \mathrm{O}_{3} 9,65 \mu \mathrm{m} \text {. Etan po- } \\
\text { siada silne maksimum absorpcji w } \\
\text { zakresach 6-7 i } 11-13 \mu \mathrm{m} \text { oraz słab- } \\
\text { sze pasmo w 3,3 } \mu \mathrm{m} \text {. }\end{array}$ & 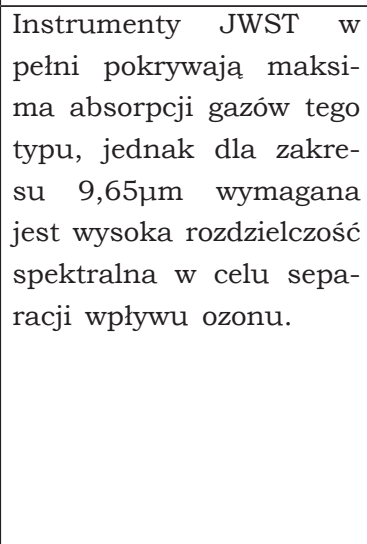 \\
\hline & $\mathrm{CH}_{3} \mathrm{Cl}$ & & $\begin{array}{l}\text { Maksima absorpcyjne w } 3,3 ; 7,0 ; \\
9,7 \text { i } 13,7 \mu \mathrm{m} \text {. }\end{array}$ & $\begin{array}{l}\text { Ze względu na pokry- } \\
\text { wanie się pasm absorp- } \\
\text { cyjnych najlepsze jest } \\
\text { pasmo absorpcyjne w } \\
\text { zakresie } 13,7 \mu \mathrm{m} .\end{array}$ \\
\hline
\end{tabular}




\begin{tabular}{|c|c|c|c|c|}
\hline \multirow[t]{2}{*}{ 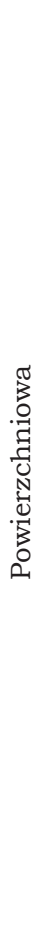 } & $\begin{array}{l}\text { Pasma ab- } \\
\text { sorpcji fo- } \\
\text { tosyntezy } \\
\text { dla dużych } \\
\text { kompleksów } \\
\text { leśnych. }\end{array}$ & $\begin{array}{l}\text { Wymagana separa- } \\
\text { cja dla obserwacji } \\
\text { ciagłych (patrz Co- } \\
\text { WAN i STRAIT 2013) } \\
\text { minimum 3". }\end{array}$ & Wymagania przedstawia Tabela 1 . & $\begin{array}{l}\text { Dla separacji z zakre- } \\
\text { su 3"-10” możliwe uży- } \\
\text { cie instrumentu NIR- } \\
\text { Spec w celu pozyskania } \\
\text { krzywych spektralnych } \\
\text { o niskiej rozdzielczości } \\
\text { z użyciem pryzmatu (R } \\
\sim 1.000) \text { dla separacji } \\
\text { >10" możliwość uzyska- } \\
\text { nia krzywych o wysokiej } \\
\text { rozdzielczości z użyciem } \\
\text { siatki szczelinowej (R } \\
\sim 3.000)\end{array}$ \\
\hline & $\begin{array}{l}\text { Wzorzec typu } \\
\text { "red edge" }\end{array}$ & j.w. & $\begin{array}{l}\text { Dla wzorca zwiazanego } z \text { pasmami } \\
\text { absorpcyjnymi chlorofili i odbiciem } \\
\text { struktury komórkowej wymagana } \\
\text { jest rejestracja w kanałach optycz- } \\
\text { nych poniżej i powyżej } 0,70 \mu \mathrm{m} \text {. W } \\
\text { zastosowaniach na Ziemi stosowa- } \\
\text { ne sa zarówno szerokie jak i wąskie } \\
\text { kanały optyczne z obszarów światła } \\
\text { czerwonego i NIR. }\end{array}$ & $\begin{array}{l}\text { Detekcja wzorca możli- } \\
\text { wa dla separacji planet } \\
\text { co najmniej } 3 \text { " (z zasto- } \\
\text { sowaniem szerokich ka- } \\
\text { nałów spektralnych), dla } \\
\text { separacji co najmniej } \\
10 " \text { możliwość użycia } \\
\text { wąskich i szerokich ka- } \\
\text { nałów optycznych. }\end{array}$ \\
\hline \multirow{2}{*}{ 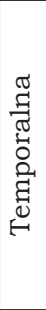 } & $\begin{array}{l}\text { Oscylacje } \\
\text { biosygnatur } \\
\text { gazowych }\end{array}$ & \multicolumn{3}{|c|}{$\begin{array}{l}\text { Jak dla biosygnatur gazowych. Dodatkowo wymagana rejestracja krzywych blasku } \\
\text { dla różnych momentów czasowych w cyklu wegetacyjnym. }\end{array}$} \\
\hline & $\begin{array}{l}\text { Oscylacje } \\
\text { biosygnatur } \\
\text { powierzch- } \\
\text { niowych }\end{array}$ & \multicolumn{3}{|c|}{ Jak dla biosygnatur powierzchniowych. } \\
\hline
\end{tabular}

ta jest widoczna $\mathrm{w}$ skali globalnej, powinna być możliwa do zaobserwowania również $\mathrm{w}$ kontekście egzoplanet.

\section{PODSUMOWANIE}

Opisane $\mathrm{w}$ tej pracy biosygnatury sa potencjalnie możliwe do obserwacji $\mathrm{w}$ pasmach UV, widzialnym i NIR. Planowany James Webb Space Telescope zawierać będzie następujace instrumenty służące obserwacji egzoplanet:

1. The Optical Telescope Element (OTE): 6,5 metrowe zwierciadło złożone $z 18$ segmentów $z$ berylu pokrytego złotem (Ryc. 5);

2. Near Infrared Camera (NIRCam): główne urzadzenie do obrazowania w bliskiej podczerwieni i częściowo $\mathrm{w}$ paśmie widzialnym $(0,6-5,0 \mu \mathrm{m})$;

3. Near InfraRed Spectrograph (NIRSpec): spektrograf umożliwiajacy pozyskanie sygnatur w zakresie 0,6-5,0 $\mu \mathrm{m}$;

4. Mid-Infrared Instrument (MIRI): instrument pozwalający pozyskać zarówno zdjęcia, jak i sygnatury $\mathrm{w}$ zakresie 5,0-28,0 $\mu \mathrm{m}$;
5. Fine Guidance Sensor pozwalajacy na precyzyjne prowadzenie instrumentów w kierunku zadanego obiektu astronomicznego.

Wybrany zakres spektralny teleskopu JWST może być użyty do obrazowania wielu biosygnatur opartych o pasmo czerwone oraz bliska i średnia podczerwień. Jest on również odpowiedni do detekcji parametrów egzoplanet opisujacych cały kontekst środowiskowy. Zestawienie wymagań instrumentów umożliwiających detekcję poszczególnych biosygnatur przedstawia Tabela 2 .

Głównymi zagrożeniami w sukcesie tej misji i potwierdzeniu badź zaprzeczeniu istnienia biosfer na najbliższych egzoplanetach sa wszystkie zagadnienia zwiazane $z$ interpretacja uzyskanych widm i zdjęć. JWST daje szansę na detekcję biosygnatur powierzchniowych dla egzoplanet, dla których rozdzielczość przestrzenna wynosić będzie co najmniej 3". Analogiczny warunek musi być spełniony dla detekcji oscylacji biosygnatur powierzchniowych. Wybrany zakres spektralny instrumentów daje możliwość detekcji większości biosygnatur gazowych. W wypadku pokrywania się zakresów pasm absorp- 
cji może jednak być wymagana wysoka rozdzielczość spektralna pozyskiwanych danych.

Szansa, jaka daje technologia zastosowana w JWST, wprowadzi astrobiologów w zupełnie nowe zagadnienia. Pozyskane dane być może po raz pierwszy będa mogły być interpretowane jako biosygnatury istniejace poza Ziemią. Trzeba pamiętać o wielu potencjalnych błędnych założeniach i interpretacjach, np. $z$ dziedziny nauk geologicznych, których przyczyna było m.in. przekładanie wprost wnioskowania opartego o warunki ziemskie na inne planety.

To, co widzimy na zdjęciach $z$ Marsa, możemy tylko przyrównać do znanych nam form geologicznych. Jednak nie wszystkie marsjańskie formy sa jednoznacznie kojarzone $z$ tym, co znamy, niekiedy stanowia one swojego rodzaju zagadkę geologiczna trudna do jednoznacznej identyfikacji i interpretacji. Teledetekcja biomasy w skali planetarnej opiera się co prawda w głównej mierze na teledetekcji związanej $z$ obszarami leśnymi ( $1 / 3$ powierzchni lądów), jednak prawdopodobnie podczas analiz danych wielospektralnych egzoplanet napotkamy zjawiska zupelnie odbiegajace od tego, co już znamy.

Wysłany na Czerwona Planetę w 2003 r. łazik Opportunity, jeden $z$ bliźniaczych łazików misji NASA Mars Exploration Rover, odkrył na powierzchni charakterystyczne, centymetrowe kulki o przyjętej nazwie blueberries (CHAN i współaut. 2007). Naukowcy zaczęli spekulować, jakiego pochodzenia sa te zagadkowe formy geologiczne. $Z$ analizy dostarczonych danych spektrometrycznych wynika, że w ich składzie znajduje się $\mathrm{m}$. in hematyt, ale konkretnej konkluzji do dzisiaj nie ustalono. $Z$ kolei sonda Mars Recconaisance Orbiter dostarcza $z$ teleskopu zwierciadlanego HiRISE wysokorozdzielcze zdjęcia powierzchni Marsa. Wiele zagadkowych form obserwowanych na tych zdjęciach do dzisiaj nie zostało wytłumaczonych. Szeregi różnych wgłębień i sferycznych struktur do niedawna interpretowane były jako kratery uderzeniowe, choć kraterami w rzeczywistości nie musza być. Modele sugeruja, że mogły one powstać chociażby przy udziale rozgrzanej magmy. Innym przykładem nierozwikłanej zagadki planetarnej sa ciemne smugi, których pochodzenie nie jest do końca wyjasnione. Wiadomo jedynie, że zjawisko to jest zwiazane $z$ procesami kriogenicznymi, kiedy w czasie wiosny marsjańskiej rozmarzaja powierzchniowe warstwy lodu i $\mathrm{CO}_{2}$, przykryte pyłem (THomAs i współaut. 2011) Tworzą się tzw. erupcje freatyczne, które wyrzucaja na powierzchnię ciemniejszy materiał, prawdopodobnie piasek bazaltowy. Całość zjawiska formuje ciekawe wzory na powierzchni w postaci smug, rzęs, pióropuszy czy też plam.

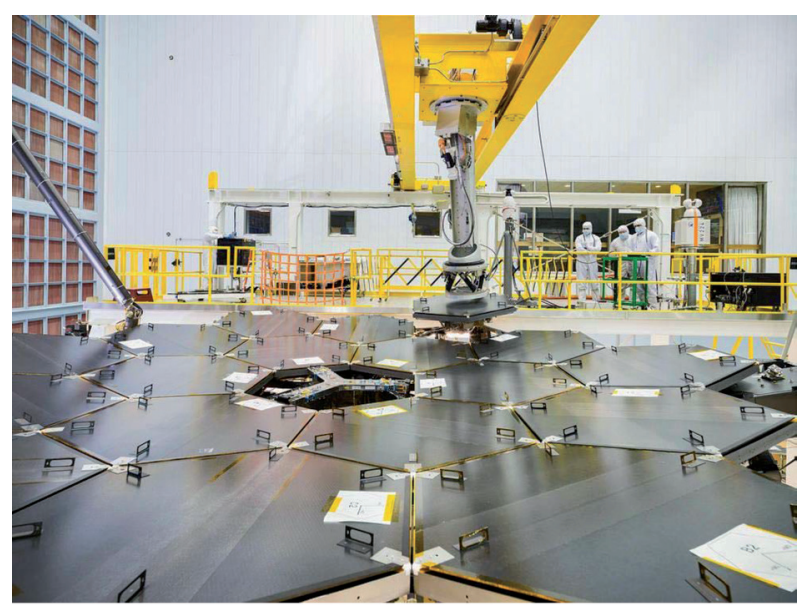

Ryc. 5. Główne zwierciadło JWST (The Optical Telescope Element) złożone z 18 heksagonalnych segmentów (źródło: jwst.nasa.gov).

Problemy w interpretacji form marsjańskich biora się m.in. stąd, że Mars nie posiada roślinności. Erozja, która występuje na Ziemi, zwiazana $z$ opadami i biosfera, nie występuje na Marsie. Zagadkowe formy sa trudne do interpretacji $z$ uwagi na swój często odmienny wygląd spowodowany zmiana w czasie, ale w zupełnie inny sposób niż na Ziemi. Często te formy są pozostałościa $z$ poczatków powstawania planety, czyli sprzed 4 miliardów lat i trwaja $w$ formie niezmienionej, podczas gdy na Ziemi już dawno uległy by destrukcji.

Należy mieć na uwadze, że tak znaczne problemy w interpretacji dotycza planety, która możemy badać metodami teledetekcyjnymi z dokładnościa do $25 \mathrm{~cm}$. Do pozyskanych przez JWST danych trzeba zatem będzie podchodzić $z$ dużą rezerwą.

Numeryczne symulacje danych obserwacyjnych przeprowadzone przez grupe T. Greene w NASA Ames Research Center wskazuja, że JWST prawdopodobnie uzyska wysokiej jakości widma transmisyjne i emisyjne atmosfer egzoplanet w zakresie długości fal co najmniej 1-11 $\mu \mathrm{m}$. Uzyskanie tego typu danych wymagać będzie co najmniej 4 obserwacji zaćmień lub tranzytów (przy założeniu, że stosunek sygnału do szumu będzie podobny jak na Hubble Space Telescope i teleskopie Spitzera). Stosunek ten może być jednak niewystarczajacy do obserwacji takich parametrów spektralnych, jak stosunek węgla do tlenu. Dodatkowo, zakres widm transmisyjnych 1-2,5 $\mu \mathrm{m}$ w symulacjach był często nieużyteczny w poprawnej detekcji biosygnatur, dlatego w celu określenia poprawnego składu atmosfer pochmurnych lub o wysokiej średniej masie czasteczkowej często wymagana będzie analiza pełnego zakresu 1-11 um (GREENE i współaut. 2016). 
Rozwiazywanie zagadnień mapowania zadanych przez modelowe sygnatury spektralne typów powierzchni (szczególnie dotyczacych podczerwieni, rejestrowane przez instrumenty NIRCam, NIRSpec i MIRI) algorytmami PCA, Rotational Unmixing (np. COWAN i STRAIT 2013), a także analizę krzywych blasku zaćmienia wtórnego (np. Williams i współaut. 2006) nie wymaga wysokiej rozdzielczości spektralnej w całym zakresie, a jedynie rejestrowania przez JWST krzywych w częstotliwościach, którymi się różnią zakładane w modelach typy powierzchni.

W celu poprawnej interpretacji otrzymanych danych niezbędna będzie zatem wiedza środowiska naukowego, na co dzień zajmujacego się teledetekcja na Ziemi, a także znajacego od praktycznej strony procesy zachodzace $\mathrm{w}$ tego typu biosferach. Umieszczenie wiosna 2019 r. wokół punktu libracyjnego $\mathrm{L}_{2}$ teleskopu JWST będzie dobra okazja do zacieśnienia współpracy środowisk zaangażowanych $\mathrm{w}$ analize danych astrofizycznych i procesów zachodzacych w biocenozie leśnej.

\section{PODZIEKOWANIA}

Autorzy dziękuja p. Robertowi Lossing z Earth Sciences Division (Goddard Space Flight Center, NASA) za cenne konsultacje i wkład merytoryczny w zakresie detekcji biomasy na powierzchniach skalistych oraz $\mathrm{w}$ oceanie, panu Wojciechowi Małeckiemu za konsultacje $\mathrm{w}$ zakresie reakcji redukcji, kierownikowi i całemu zespołowi Zakładu Teledetekcji za nieustanna inspiracje w podejmowaniu nietypowych zagadnień. W publikacji wykorzystano m.in. wyniki, które powstały w ramach projektu HESOFF (LIFE11 ENV/PL/000459).

\section{Streszczenie}

Teledetekcja czynników związanych $\mathrm{z}$ występowaniem obszarów zalesionych jest dziedzina nauki, która zgromadziła nieoceniona ilość danych dotyczacych procesów zachodzacych w ekosystemach leśnych w mikro- $\mathrm{i}$ makroskali. W naszej publikacji skupiamy się na biosygnaturach lasów, których detekcja na najbliższych Ziemi egzoplanetach teoretycznie mogłaby być prowadzona w oparciu o dane wielospektralne rejestrowane przez majacy rozpoczać pracę wiosna 2019 r. Kosmiczny Teleskop Jamesa Webba (JWST ang. John Webb Space Telescope). W tym kontekście analizujemy możliwość i metody detekcji biosygnatur gazowych (np. $\mathrm{O}_{2}, \mathrm{CO}_{2}$, metanu), powierzchniowych (np. wzorca „red edge”, pasm absorpcji pigmentów) oraz opartych na zmienności sygnatur spektralnych, które moga być rezultatem sezonowych procesów w biosferze. Wyniki tego przegląu odnosimy do historycznych badań najbardziej znanego środowiska planetarnego poza Ziemia, Marsa. Postulujemy wykorzystanie w przyszłych badaniach nad egzoplanetami wyników prac teledetekcyjnych oraz modelujacych zjawiska zachodzace $\mathrm{w}$ ekosystemach leśnych na Ziemi. Zwracamy jednak uwagę na potrzebę wielkiej ostrożności $\mathrm{w}$ interpretacji uzyskanych wyników.

\section{LITERATURA}

BERDYUGINA S. V., KUHN J. R., 2017. Surface imaging of proxima $b$ and other exoplanets: topography, biosignatures, and artificial mega-structures. preprint arXiv, 1711.00185.

Ciais P., TANS P. P., TROlier M., White J. W. C., FRANCEY R. J., 1995. A large northern hemisphere terrestrial $\mathrm{CO} 2$ sink indicated by the $13 \mathrm{C} / 12 \mathrm{C}$ ratio of atmospheric CO2. Science 269, 1098-1102.

Chakrabarti S., Mendillo C. B., Cook T. A. i współaut., 2016. Planet Imaging Coronagraphic Technology using a Reconfigurable Experimental Base (PICTURE-B): The second in the series of suborbital exoplanet experiments. J. Astronom. Instrument. 5, 1640004.

ChAN M. A., ORMO J., PARK A. J., 2007. Models of iron oxide concretion formation: field, numerical, and laboratory comparisons. Geofluids $7,1-13$

ClaUdI R., 2017. Exoplanets: possible biosignatures. preprint arXiv: 1708.05829.

CowAN N. B., STRAIT T. E., 2013. Determining reflectance spectra of surfaces and clouds on exoplanets. Astrophys. J. Lett. 765, L17.

Clark R. N., SWAYZE G. A., WISE R. i współaut., 2007. USGS digital spectral library splib06a. US Geol. Survey Publ., https://pubs.er.usgs. gov/publication/ds231.

CZAPSKI P., KOTLARZ J., KUBIAK K., TKACZYK M., 2014. Analiza czynnikowa zdjeć wielospektralnych. Prace Instytutu Lotnictwa 1, 143-150.

CZAPSKI P., KACPRZAK M., KOTLARZ J., MROWIEC K., KUBIAK K., TKACZYK M., 2015. Preliminary analysis of the forest health state based on multispectral images acquired by Unmanned Aerial Vehicle. Folia Forestalia Polo. 57, 138144.

Des Marais D. J., HaRwit M. O., Jucks i współaut., 2002. Remote sensing of planetary properties and biosignatures on extrasolar terrestrial planets. Astrobiology 2, 153-181.

Des MaRais D. J., NUTH III J. A., Allamandola L. J., Boss i współaut., 2008. The NASA astrobiology roadmap. Astrobiology 8, 715-730.

Doughty C. E., Metcalfe D. B., Girardin C. A. J., AMÉzQUiTA F. F. i współaut., 2015. Drought impact on forest carbon dynamics and fluxes in Amazonia. Nature 519, 78-82.

DRESSLER A., BROWN R. A., DAVIDSEN A. F. i współaut., 1996. Exploration and the search for origins: a vision for ultraviolet-optical-infrared space astronomy. Association of Universities for Research in Astronomy.

FitZPATRICK M. R., PEARSON K., GRIFFith C. A., $i$ współaut., 2016. A study of the effects of underlying assumptions in the reduction of multi-object photometry of transiting exoplanets. Am. Astronom. Soc. Meeting, 227.

FUJII Y., LUSTIG-YAEGER J., COWAN N. B., 2017. Rotational spectral unmixing of exoplanets: degeneracies between surface colors and geography. Astronom. J. 154, 189.

FUHRMANN D. R. 1999. Simplex shrink-wrap algorithm. [W:] Automatic target recognition IX. International Society for Optics and Photonics 3718, 501-512.

Grenfell J. L., Gebauer S., Godolt M., PALCZYNSKI K., RAUER H., STOCK J., VON PARIS P., LEHMANN R., SElsis F., 2013. Potential biosignatures in super-Earth atmospheres II. Photochemical responses. Astrobiology 13, 415-438

Greene T. P., Line M. R., Montero C., ForTney J. J., LUSTig-YAEgeR J., LUTHER K., 2016. 
Characterizing transiting exoplanet atmospheres with JWST. Astrophys. J. 817, 17.

Hansen K., PERSONNE E., SKJøTH C. A. i współaut., 2017. Investigating sources of measured forest-atmosphere ammonia fluxes using two-layer bi-directional modelling. Agricul. Forest Meteorol. 237, 80-94.

Horler D. N. H., DOCKRAY M., BARBER J., 1983. The red edge of plant leaf reflectance. International Journal of Remote Sensing, 4(2), 273-288.

KACPRZAK M., KotlaRZ J., KUBIAK K., RotCHIMMEL K., TKACZYK M., 2018. Metodyka oszacowania defoliacji Quercus Robur L. na podstawie analizy reflektancji $w$ zakresie 0,64-0,73 $\mu \mathrm{m}$. Technika Rolnicza Ogrodnicza Leśna 1, 1519.

KASTING J. F., WhitMiRe D. P., Reynolds R. T., 1993. Habitable zones around main sequence stars. Icarus $101,108-128$.

KaSting J. F., KopPaRAPU R., RAMIREZ R. M., HARMAN C. E., 2014. Remote life-detection criteria, habitable zone boundaries, and the frequency of Earth-like planets around $M$ and late $K$ stars. Proc. Natl. Acad. Sci. USA 111, 1264112646.

Kolusu S. R., SchlünZen K. H., GRAWE D., SEIFERT R., 2018. Determination of chloromethane and dichloromethane in a tropical terrestrial mangrove forest in Brazil by measurements and modelling. Atmosph. Environ. 173, 185197.

KOPPARAPU R. K., RAMIREZ R., KASTING J. F i współaut., 2013. Habitable zones around main-sequence stars: new estimates. Astrophys. J. $765,131$.

KOTLARZ J., KACPRZAK M., 2017. Algorytm automatycznego oszacowania zróżnicowania gatunkowego drzewostanu $z$ wykorzystaniem zdjęć RGB koron drzew. Pomiary Automatyka Robotyka, 21

KotlaRZ J., KUBIAK K., KACPRZAK M., CZAPSKI P., 2016. Estimation of tree species diversity of forest stands based on their spectral reflectance. Sylwan 160, 1036-1045.

KUBIAK K., MAZUR. A, SKOCKI K., 2016. Laboratory spectral analyses. Raport techniczny $Z$ prac wykonywanych w projekcie HESOFF.

LuTSCH E., Dammers E., CONWAY S., STRONG K., 2016. Long-range transport of NH3, CO, HCN, and $\mathrm{C} 2 \mathrm{H} 6$ from the 2014 Canadian Wildfires. Geophys. Res. Lett. 43, 8286-8297.

MANNE J., BuI T., Christopher R. Q., WeBster C. R., 2017. Determination of foreign broadening coefficients for Methane Lines Targeted by the Tunable Laser Spectrometer (TLS) on the Mars Curiosity Rover. J. Quant. Spectr. Radiat. Transfer 191, 59-66.

MarcQ E., Salvador A., Massol H., Davaille A., 2017. Thermal radiation of magma ocean planets using a $1 D$ radiative-convective model of $\mathrm{H}_{2} \mathrm{O}-\mathrm{CO}_{2}$ atmospheres. J. Geophys. Res. Planets, doi.org/10.1002/2016JE005224.

MEadows V. S., 2017. Reflections on $O_{2}$ as a biosignature in exoplanetary atmospheres. Astrobiology 17, 1022-1052.

Meadows V. S., Reinhard C. T., ARney G. N. i współaut., 2017. Exoplanet biosignatures: understanding oxygen as a biosignature in the context of its environment. preprint arXiv, 1705.07560.

NASIŁOWSKA S., KaCPRZAK M., KotLARZ J., RYNKIEWICZ A., ROTCHIMMEL K., 2016. Teledetekcja $w$ badaniu wpływu suszy na stan zdrowotny drzewostanów dębowych. Konferencja: „Drze- wa i lasy w zmieniajacym się środowisku", Instytut Dendrologii PAN.

Ollivier M., MAUREL M. C., 2014. Planetary environments and origins of life-how to reinvent the study of origins of life on the earth and life in the Universe under the light of exoplanetology progress. [W:] BIO Web of Conferences. EDP Sciences 2, 00001

PANGala S. R., HORNIBROOK E. R., GOWING D. J., GAUCI V., 2015. The contribution of trees to ecosystem methane emissions in a temperate forested wetland. Global Change Biol. 21, 2642-2654.

Parmentier V., Guillot T., Showman A. P., ForTNEY J., MARLEY M., 2015. Characterizing exoplanets atmospheres with space photometry at optical wavelengths. [W:] EPJ Web of Conferences. EDP Sciences 101, 02002.

PluTO-KOSSAKOWSKa J., OSIŃSKA-SKOTAK K., STEREŃCZAK K., 2017. Określenie rozdzielczości przestrzennej wielospektralnych zdjeć satelitarnych optymalnej do detekcji martwych drzew na obszarach leśnych. Sylwan 161, 395-404.

RAHN T., EILER J. M., Kitchen N., FESSENDEN J. E., RANDERSON J. T., 2002. Concentration and $\delta D$ of molecular hydrogen in boreal forests: Ecosystem-scale systematics of atmospheric H2. Geophys. Res. Lett., doi. org/10.1029/2002GL015118.

RoBINSON T. D., 2017. Characterizing exoplanets for habitability. preprint arXiv, 1701.05205.

Robinson T. D., EnNico K., MEADOWS V. S. i współaut., 2014. Detection of ocean glint and ozone absorption using LCROSS Earth observations. Astrophys. J. 787, 171.

SCHWIETERMAN E. W., COCKELl C. S., MEAdows V. S., 2015. Nonphotosynthetic pigments as potential biosignatures. Astrobiology 15, 341361.

SchWieterman E. W., KIANG N. Y., PARENTEAU i współaut., 2017. Exoplanet biosignatures: a review of remotely detectable signs of life. preprint arXiv, 1705.05791.

SEAGER S., TURNER E. L., Schafer J., FORD E. B., 2005. Vegetation's red edge: a possible spectroscopic biosignature of extraterrestrial plants. Astrobiology 5, 372-390.

STEIgENBERGER S., TERJUng F., GROSSART H. P., REUTER R., 2004. Blue-fluorescence of NADPH as an indicator of marine primary production. EARSeL eProceedings 3, 18-25.

TinetTi G., RASHBY S., YUNG Y. L., 2006. Detectability of red-edge-shifted vegetation on terrestrial planets orbiting $M$ stars. Astrophys. J. Lett. 644, L129.

Thomas N., PoRtyankina G., Hansen C. J., POMMEROL A., 2011. HiRISE observations of gas sublimation-driven activity in Mars' southern polar regions: IV. Fluid dynamics models of CO2 jets. Icarus 212, 66-85.

TUCKER C. J., 1979. Red and photographic infrared linear combinations for monitoring vegetation. Remote Sens. Environ. 8, 127-150.

TURnBull M. C., TRAUB W. A., JUCKS K. W. i współaut., 2006. Spectrum of a habitable world: Earthshine in the near-infrared. Astrophys. J. 644, 551.

UDALSKI A., JAROSZYŃSKI M., PACZYŃSKI B. i współaut., 2005. A jovian-mass planet in microlensing event OGLE-2005-BLG-071. Astrophys. J. Lett. 628, L109.

Wei J., AMElung W., LehndorfF E., Schloter M., VEREECKEN H., BRÜGGEMANN N., 2017. N2O and NOx emissions by reactions of nitrite with soil organic matter of a Norway spruce forest. Biogeochemistry 132, 325-342. 
WeI S., ZHONG-QUAN Q., 2017. Polarimetric study of an Earth-like Planet. Chin. Astr. Astrophys. 41, 235-253.

Williams P. K., Charbonneau D., COOPER C. S., Showman A. P., FORTNEY J. J., 2006. Resolving the surfaces of extrasolar planets with secondary eclipse light curves. Astrophys. J. 649, 1020.

WITEK P., CZECHOWSKI L., 2016. Morphology of river deltas on Earth and Titan. [W:] EGU General Assembly. Conference abstracts. Geophys. Res. Abstracts 18, 14415.

WolstencRofT R. D., RAVEN J. A., 2002. Photosynthesis: likelihood of occurrence and possi- bility of detection on Earth-like planets. Icarus $157,535-548$.

ZaleWSKA N., 2013. Hellas Planitia as a potential site of sedimentary minerals. Planet Space Sci. 78, 25-32.

ZALEWSKA N., KOTLARZ J., KACPRZAK M., KORNILUK T., 2017. Detekcja biomarkerów w pióropuszach gazowych za pomoca kamery wielospektralnej $w$ projektowanej misji Enceladus Orbiter (NASA). Pomiary Automatyka Robotyka 21, 35-44.

KOSMOS Vol. 67, 4, 709-720, 2018

\author{
JAN KOTLARZ ${ }^{1}$, NATALiA ZALEWSKA ${ }^{1,2}$
}

${ }^{1}$ Remote Sensing Division, Institute of Aviation, 110/114 Al. Krakowska Str., 02-256 Warszawa, ${ }^{22}$ Space Research Center PAS, 18A Bartycka Str., 00-716 Warszawa,E-mail: jan.kotlarz@ilot.edu.pl, natalia.zalewska@ilot.edu.pl

SPECTRAL CHARACTERISTICS IN THE VISIBLE AND INFRARED REGIONS OF EXOPLANETS WITH FORESTTYPE SURFACE. STATE OF KNOWLEDGE BEFORE JWST MISSION

\title{
Summary
}

Remote sensing of forest areas is a field of science that has gained an invaluable amount of data describing processes in forest ecosystems in micro- and macro-scale. In this paper, we focus on biosignatures of forests, whose detection on the nearest Earth exoplanets theoretically could be conducted on the basis of multispectral data recorded by the James Webb Space Telescope (JWST), whose mission will start in the spring 2019. In this context, we analyze possibilities and methods of detection of the following types of biosignatures: gas (e.g. $\mathrm{O}_{2}, \mathrm{CO}_{2}, \mathrm{methane}$ ), surface (e.g. "red edge" pattern, pigment absorption bands) and spectral signatures based on variations that may result from seasonal processes in the biosphere. The results presented in this review are referred to the past studies on Mars, with the best known planetary environment besides the Earth. We postulate the usage of the forest areas remote sensing projects and modeling phenomena occurring in forest ecosystems on Earth in future exoplanet research. However, we draw attention to the need for great caution in interpreting the obtained results.

Keywords: biosignatures, exoplanets, JWST, photosynthesis, red edge, remote sensing 